\title{
НАУКОВО-ТЕОРЕТИЧНІ ОСНОВИ ФОРМУВАННЯ СОЦІОКОМУНІКАТИВНОЇ КОМПЕТЕНТНОСТІ МАЙБУТНІХ ЛІКАРІВ У ПРОЦЕСІ ВИВЧЕННЯ ПРИРОДНИЧИХ ДИСЦИПЛІН
}

\section{Шевчук Т. І., Хлєстова С. С.}

\section{ВСТУП}

У Національній стратегії розвитку освіти в Україні на період до 2021 року наголошується, що «сучасний ринок праці вимагає від випускника не лише глибоких теоретичних знань, а й здатності самостійно застосовувати їх у нестандартних, постійно змінюваних життєвих ситуаціях, переходу від суспільства знань до суспільства життєво компетентних громадян» ${ }^{1}$.

Питання підвищення ефективності підготовки медичних кадрів, формування у них соціокомунікативної компетентності і готовності до міжособистісної взаємодії в рамках професійної сфери є одними iз ключових завдань педагогіки. Соціокомунікативна компетентність майбутнього лікаря - це базова інтегральна характеристика, яка відображає рівень уміння людини взаємодіяти, чи контактувати, з іншими особами. У професійній діяльності майбутній лікар виступає активним суб'єктом спілкування: передає та приймає інформацію від пацієнтів, колег i адміністрації, установлює контакти з ними, будує взаємовідносини на основі діалогу, розуміє $\mathrm{i}$ сприймає внутрішній світ людини. Цим визначається важливість сформованості у майбутніх лікарів соціокомунікативної компетентності. Отримані студентами-медиками знання під час вивчення природничих дисциплін сприятимуть засвоєнню суспільних цінностей, норм, правил, еталонів соціально схвальної поведінки і забезпечуватимуть успішність соціальної і професійної взаємодії, гармонію у відносинах з іншими людьми та навколишнім світом.

Професійна лікарська діяльність має певні особливості. 3 одного боку, важливе місце займає високий рівень міжособистісних контактів при спілкуванні 3 пацієнтами, їх родичами, а також

\footnotetext{
${ }^{1}$ Національна стратегія розвитку освіти в Україні на 2012-2021 роки. URL: http://oneu.edu.ua/wp-content/uploads/2017/11/nsro_1221.pdf. 
3 колегами та керівництвом, 3 іншого - робота лікаря характеризується психоемоційними перевантаженнями, високим ступенем напруження, що призводить до зниження їх комунікативних здібностей і виникнення певних труднощів у спілкуванні. Тому значну увагу необхідно приділяти розвитку комунікативної грамотності майбутніх лікарів, що має пряме відношення до задоволення пацієнта допомогою, яку йому надає лікар.

Майбутні фахівці медичної сфери повинні бути не лише професіоналами в своїй галузі, а й володіти комунікативними, організаторськими, лідерськими та іншими здібностями ${ }^{2}$.

Отже, одним із першочергових завдань вищої освіти $\epsilon$ формування соціокомунікативної компетентності майбутнього лікаря, оскільки вона виступає духовно-моральним чинником i науковим змістом освітнього процесу, де знання лікаря, гуманність, душевна щедрість, бажання зрозуміти i допомогти пацієнту відіграють головну роль.

Метою дослідження $€$ теоретичний аналіз проблеми формування соціокомунікативної компетентності майбутніх лікарів у педагогічній теорії та визначення сутності основних понять наукового дослідження.

Для досягнення поставленої мети проведено аналіз наукових джерел із педагогіки, психології, філософії і соціології з метою розкриття сутності основних понять дослідження; аналіз навчальнометодичних посібників з означеної проблеми; аналіз нормативноправової документації щодо професійної підготовки лікарів; аналіз та узагальнення досвіду роботи 3 проблеми дослідження для обгрунтування організаційно-педагогічних умов формування соціокомунікативної компетентності майбутніх лікарів у процесі вивчення природничих дисциплін.

\footnotetext{
${ }^{2}$ Воробьева А.В. Коммуникативная компетентность молодого специалиста медицинского профиля как одна из основных квалификационных составляющих его профессиональной деятельности. Вестник новых медицинских технологий, электронный журнал. 2017. № 2. C. 373-378. URL: https://cyberleninka.ru/article/ $\mathrm{n} /$ kommunikativnaya-kompetentnost-molodogo-spetsialista-meditsinskogo-profilya-kakodna-iz-osnovnyh-kvalifikatsionnyh-sostavlyayuschih/viewer.
} 


\section{1. Проблеми формування соціокомунікативної компетентності майбутніх лікарів у педагогічній теорії}

Сьогодні перед державою стоять завдання забезпечити пріоритетність розвитку освіти і науки з метою задоволення потреб особистості, суспільства i держави. Актуальним $\epsilon$ зміцнення навчальної матеріальної бази, комп'ютеризація навчальних закладів, впровадження новітніх інформаційних технологій, забезпечення професійної підготовки науково-педагогічних працівників, проведення управлінських реформ, налагодження міжнародного співробітництва, реалізація стратегічного європейського та євроатлантичного курсу держави ${ }^{3}$.

У сучасних умовах глобалізації всіх сфер життєдіяльності людини i загальноцивілізаційних тенденцій зростання міжнародних зв'язків важливим завданням вищих навчальних закладів $\epsilon$ підготовка мобільних i компетентних фахівців, які здатні інтегруватися в різні соціуми, активно діяти, самовизначатися i самостверджуватися, бути конкурентноздатними на світовому ринку праці, вміти прогнозувати соціальні тенденції розвитку суспільства, вирішувати конкретні практичні проблеми, пов'язані 3 професійною діяльністю ${ }^{4}$. Це зумовлює пошук ефективних моделей підготовки фахівців, однією 3 яких $\epsilon$ застосування компетентнісного підходу, який своєю чергою передбачає інтеграцію теоретичної і практичної компоненти підготовки фахівців у вищих навчальних закладах 3 метою формування в нього певних компетенцій, що сприяють його швидкій адаптації на ринку праці, успішному розв'язанню життєвих, особистіних, професійних завдань для самовизначення, саморозвитку і самореалізації5.

${ }^{3}$ Указ Президента України «Питання європейської та євроатлантичної інтеграції» від 20.04.2019 № 155/2019. URL: https://zakon.rada.gov.ua/go/155/2019.

4 Романовська О. Особливості організації процесу професійної підготовки студентів інженерно-педагогічних ВНЗ щодо проблеми формування їхньої конкурентноздатності. Молодь і ринок. 2015. № 5. С. 75-79. URL: http://nbuv.gov.ua/ UJRN/Mir 2015519.

5 Антіпова $\bar{H}$. П. Сутність поняття «компетентнісний підхід» в науковопедагогічній літературі. Науковий вісник Національного університету біоресурсів $i$ природокористування Украӥни. Серія : Педагогіка, психологія, філософія. 2014. Вип. 199(1). С. 28-32. URL: http://nbuv.gov.ua/UJRN/nvnau ped_2014_199\%281\%29_5. 
Компетентнісний підхід сприяє формуванню всебічно розвиненої особистості з новим світоглядом і типом мислення, що дозволить йому за бажанням обирати місце роботи, забезпечить кращу адаптованість і мобільність, можливість успішно конкурувати на ринку праці.

Реалізація компетентнісного підходу передбачає орієнтацію освіти на формування компетентностей, оновлення освітньої політики загалом, навчально-методичного забезпечення, розширення міждисциплінарної інтеграції, застосування інноваційних технологій навчання, збільшення частки різних видів практик, забезпечення навчального процесу кваліфікованими кадрами тощо ${ }^{6}$.

Якість медичної освіти залежить від багатьох факторів: від мотивації і бажання вчитися самих студентів, від компетентності науково-педагогічних працівників, методичного забезпечення навчального процесу, використання сучасних технологій навчання; від організації науково-дослідної роботи в навчальному закладі, від наявності системи заохочення і контролю знань та вмінь.

Підготовка висококваліфікованих, конкурентоздатних спеціалістів, які зможуть приймати відповідальні, нестандартні рішення та прогнозувати їх наслідки, вимагає відповідної професійної підготовки науково-педагогічних працівників вищих медичних закладів, які мають використовувати у своїй діяльності інноваційні форми i методи навчання, системний, компетентнісний i міждисциплінарний підходи щодо організації навчального процесу, формувати у майбутніх лікарів клінічне мислення, здатність до ефективної взаємодії 3 оточуючими та реалізації своїх професійних здібностей ${ }^{7}$.

Якщо раніше для підтвердження кваліфікації фахівця достатньо було мати певну сукупність знань та вмінь, то зараз основною характеристикою будь-якого спеціаліста $\epsilon$ його професійна компетентність, яка формується завдяки застосуванню компетентнісного підходу в процесі здобуття освіти у вищому навчальному закладі. Одним із складників професійної компетентності $\epsilon$ соціокомунікативна компетентність.

${ }^{6}$ Овсієнко Л. Компетентнісний підхід до навчання: теоретичний аналіз. Педагогічний процес: теорія і практика. 2017. Вип. 2. С. 82-87.

${ }^{7}$ Демянчук М. Р. Компетентнісний підхід до формування культури професійного спілкування майбутніх лікарів. Вісник Черкаського університету. 2016. Вип. 18. C. 45-51. URL: http://ped-ejournal.cdu.edu.ua/article/view/1153/1226. 
Наявність соціокомунікативної компетентності у фахівця свідчить про його теоретичну обізнаність і практичну готовність здійснювати ефективну професійну діяльність, яка пов'язана 3 налагодженням i підтримкою постійних міжособистісних контактів, з прийняттям колективних рішень, досягненням певних цілей та умінням працювати в команді ${ }^{8}$.

Сьогодні вища медична освіта не забезпечує формування високого рівня соціокомунікативної компетентності майбутніх лікарів. Під час професійної підготовки медиків вирішальними вважаються точні, фундаментальні і клінічні дисципліни без урахування соціокомунікативного аспекту фахової підготовки.

Але професія лікаря має певні специфічні особливості, які пов'язані 3 великою кількістю міжособистісних контактів, взаємовідносинами 3 пацієнтами та їх родичами, стосунками в колективі, 3 керівництвом i молодшим медперсоналом. Професійна діяльність лікаря характеризується високим рівнем комунікативної взаємодії, психоемоційним та інформаційним перевантаженням, необхідністю швидко приймати рішення стосовно здоров'я інших людей, адаптуватися до змінних умов оточуючого середовища, тому формування у майбутніх медиків соціокомунікативної компетентності $€$ важливим завданням вищої медичної школи 9 .

У галузевому стандарті вищої освіти підготовки на другому (магістерському) рівні у галузі знань 22 «Охорона здоров'я» у переліку загальних компетентностей передбачено формування у студентів медиків здатності до застосування знань на практиці, адаптації та дії в новій ситуації, працювати в команді, формування навичок міжособистісної взаємодії, використання комунікаційних технологій, а також діяти соціально, відповідально та свідомо.

Професійною компетентністю лікаря називають комплекс знань, умінь і навичок, які зумовлюють його здатність працювати за фахом. Важливим моментом у формуванні професійної компетентності лікаря $є$ його вміння здійснювати соціальну взаємодію (розуміння відчуттів і думок інших людей, врахування чужої точки зору,

\footnotetext{
${ }^{8}$ Давискиба В.О. Проблема формування професійної компетентності фахівців у сучасних наукових дослідженнях. Духовність особистості: методологія, теорія $i$ практика. 2017. Вип. 6. С. 75-81. URL: http://nbuv.gov.ua/UJRN/domtp_2017_6_11.

${ }^{9}$ Павлюк Т. В., Толокова Т. І. Особливості емоційної сфери медичних працівників. Медична освіта. 2018. № 1. C. 103-107. URL:https://core.ac.uk/reader/ 276622410. 
контроль своєї поведінки, повага до колег і пацієнтів), а також реалізувати комунікативний компонент (дотримання правил спілкування, вміння слухати інших і висловлювати свої думки, поважати оточуючих) і працювати в команді (вміння співпрацювати 3 колегами, приймати спільне рішення) ${ }^{10}$.

На думку деяких вчених, формування професійно-комунікативної компетентності студентів-медиків має здійснюватися через позитивне ставлення до праці як необхідної соціальної діяльності індивіда, його залучення до системи культурних і моральних цінностей, через розуміння і повагу до потреб, цінностей і поглядів інших людей; через формування культури поведінки і спілкування, розвиток інтелігентності, порядності, милосердя та співчуття; а також здатності до самоаналізу, самооцінки і саморегуляції ${ }^{11}$.

Професія лікаря передбачає налагодження міжособистісних контактів, уміння спілкуватися 3 пацієнтами i їх родичами. У цьому контексті слід відмітити такі професійно важливі якості лікаря: толерантність, ввічливість, співчуття, тактовність, спостережливість, вміння обгрунтувати призначення певних діагностичних чи лікувальних маніпуляцій, індивідуальний підхід до кожного пацієнта, вміння пояснювати певні психологічні реакції хворого.

До необхідних якостей лікаря відносять вміння бути переконливим в бесіді з пацієнтом, проявляти повагу до колег і їх думок, володіння технікою слухання i спостереження за пацієнтом, навичками встановлення первинного контакту, усунення можливих протиріч, корекції конфліктної поведінки пацієнтів, вміння взаємодіяти 3 депресивними і конфліктними пацієнтами, вміння ведення і коректного завершення бесіди, використання вербальних і невербальних засобів спілкування, вибирати адекватний стиль спілкування, під час якого

${ }^{10}$ Лимар Л.В. Зміст і складові професійної компетентності сімейного лікаря: психологічний аспект. Вісник післядипломної освіти. Серія «Соціальні та поведінкові науки». 2019. Вип. 8 (37). С. 67-83.

11 Лукаш Ю.М. Основні аспекти формування професійно-комунікативної компетентності студентів-медиків у процесі вивчення соціально-гуманітарних дисциплін. Вісник університету імені Альфреда Нобеля. Сер. Педагогіка $i$ психологія. Педагогічні науки. 2018. № 1(15). С. 150-156. 
встановлювати основні причини хвороби і вибудовувати разом 3 пацієнтом схему діагностичних і лікувальних процедур ${ }^{12}$.

Складником професійної компетентності лікаря $є$ його соціальна компетентність. Соціальну компетентність характеризують як набір знань, умінь та навичок, які забезпечують ефективну взаємодію лікаря 3 пацієнтами, їх родичами, 3 колегами, керівництвом та іншими структурами охорони здоров'я ${ }^{13}$. Лікар має бути мотивований щодо своєї професії і соціальної взаємодії; володіти знаннями про культуру спілкування, способи і форми взаємодії з оточуючими, деонтологічну культуру; вміти обирати стиль спілкування, стратегію поведінки, а також здійснювати самоспостереження і контроль за своїми емоціями.

Професійно-комунікативна компетентність майбутніх лікарів включає спеціальні знання і вміння, які дозволяють функціонувати в соціумі; здатність вступати в діалог, підтримувати його, підтримувати його і бути зрозумілим; вміння встановлювати регулярні комунікативні контакти та успішно працювати з іншими співробітниками, розробляти колективні рішення та реалізувати їх на практиці; вміння правильно формулювати власну професійну думку, відстоювати і враховувати суспільногромадську позицію.

\section{2. Визначення сутності основних понять наукового дослідження}

Дослідження проблеми формування соціокомунікативної компетентності у студентів-медиків вимагає визначення сутності і деталізації основних понять, а також встановлення взаємозалежності і взаємозв'язку між ними. У науковій літературі відмічається неоднозначність до визначення термінів «компетентність» і «компетенція», тому доцільно розглянути тлумачення цих понять різними словниками.

${ }^{12}$ Коммуникативный компонент содержания образования в аспекте корпоративной культуры медицинского вуза / Фомина М.В. и др. Вестник Оренбургского государственного университета. 2018. № 6 (218). C. 91-96. URL: https://cyberleninka.ru/ article/n/kommunikativnyy-komponent-soderzhaniya-obrazovaniya-v-aspektekorporativnoy-kultury-meditsinskogo-vuza/viewer.

13 Лимар Л.В. Основні компоненти соціальної компетентності сімейних лікарів в Україні. Медична освіта. 2019. № 2. С. 90-95. 
У словниках іншомовних слів компетентність визначається як обізнаність, поінформованість, авторитетність, а компетенція як коло повноважень якої-небудь організації або особи; коло питань, з яких дана особа має певні знання, досвід, повноваження. Згідно 3 словником української мови компетентною вважається людина, яка має достатні знання в якій-небудь галузі, є обізнаною i тямущою або має певні повноваження, повновладна ${ }^{14}$.

Великий тлумачний словник сучасної української мови В. Бусела схоже трактує ці поняття: «компетентний»: як той, який грунтується на знанні, кваліфікований, який має певні повноваження, повноправний, повновладний; поняття «компетентність» - як поінформованість, обізнаність, авторитетність, а поняття «компетенція» як добра обізнаність з чим-небудь, коло повноважень якої-небудь організації, установи або особи 15 .

У чинному законі України «Про вищу освіту» (стаття 1, пункт 13) сказано, що компетентність - здатність особи успішно соціалізуватися, навчатися, провадити професійну діяльність, яка виникає на основі динамічної комбінації знань, умінь, навичок, способів мислення, поглядів, цінностей, інших особистих якостей ${ }^{16}$.

«Компетентності» i «компетенції» виступають базовими поняттями компетентнісного підходу, основними характеристиками якого $\epsilon$ : орієнтація на формування особистості фахівця, міждисциплінарна модель навчання, впровадження в навчальний процес інтерактивних форм навчання, професійно-орієнтована спрямованість, у результаті чого у випускника формуються певні компетенції, які забезпечують виконання професійних завдань, орієнтацію в суміжних галузях діяльності, готовність до постійного професійного і особистісного розвитку, соціальної і професійної мобільності ${ }^{17}$.

${ }^{14}$ Сучасний тлумачний словник української мови : 50000 слів: оптимальна добірка слів з усіх галузей знань / за ред. В.В. Дубічинського. Київ : Школа, 2006. 832 c.

${ }^{15}$ Великий тлумачний словник сучасної української мови : 250000 / укл. та гол. ред. В. Т. Бусел. Київ; Ірпінь : Перун, 2005. VIII, 1728 с.

16 Закон України «Про вищу освіту» від 01.07.2014. № 1556-VII. URL: http://zakon4.rada.gov.ua/laws/show/1556-18.

17 Кустовська I.M. Компетентнісний підхід у професійній підготовці фахівця. Вісник Наџіональної академії Державної прикордонної служби України. Сер. Педагогіка. 2015. Вип. 5. URL: http://nbuv.gov.ua/UJRN/Vnadped_2015_5_13. 
Сьогодні компетентність розглядається як динамічна комбінація знань, вмінь, навичок, способів мислення, професійних, світоглядних і громадянських якостей, морально-етичних цінностей, яка визначає здатність особи успішно здійснювати професійну та подальшу навчальну діяльність і $є$ результатом навчання на певному рівні вищої освіти ${ }^{18}$.

Згідно з Проектом Тюнінг компетентність - це динамічне поєднання когнітивних та метакогнітивних вмінь та навичок, знань та розуміння міжособистісних, розумових та практичних вмінь та навичок і етичних цінностей; компетентності покладені в основу кваліфікації випускника. Компетентності поділяються на загальні і предметні (специфічні для певної галузі). У проєкті виділено три групи загальних компетентностей: інструментальні (когнітивні, методологічні, технологічні та лінгвістичні здатності), міжособистісні (соціальна взаємодія і співпраця) і системні (уміння і навички, що стосуються систем загалом) ${ }^{19}$.

Науковець М. Леонтян диференціює поняття «компетентності» і «компетенції», зазначаючи, що компетентність - це значно ширше поняття, оскільки свідчить про готовність людини діяти в певних ситуаціях через особистісну характеристику, через перехід від якості знань до якості діяти в нестандартних умовах. А компетенції автор ототожнює 3 певними питаннями, в яких людина добре обізнана, а також як сукупність знань, умінь, навичок і досвіду, які передбачають дію у стандартних ситуаціях ${ }^{20}$.

Розмежовують поняття «компетентність» і «компетенція» й інші автори. Так, С. Лейко під компетенцією розуміє певну сферу діяльності, в якій особистість має бути добре обізнана; компетенція визначається організацією, установою, закладом, державою як сукупність знань, умінь, навичок і власного до них ставлення, що забезпечить успішну діяльність в певній галузі. А компетентність характеризується як власна якісна характеристика, що дозволяє застосовувати отримані знання й уміння на практиці, враховуючи

\footnotetext{
${ }^{18}$ Козлова Г.М. Методика викладання у вищій школі: навч. посібн. Одеса : НЕУ, ротапринт, 2014. $200 \mathrm{c}$.

19 Сисоєва С.О., Соколова І.В. Теорія і практика вищої освіти: навчальний посібник. 2016. 338 с.

20 Леонтян М.А. Поняття «компетенція» і «компетентність» у теорії освіти. Наукові праці [Чорноморського держ. ун-ту ім. Петра Могили комплексу «КиєвоМогилянська академія»]. Сер. Педагогіка. 2012. Т. 188, Вип. 176. С. 73-75. URL: http://nbuv.gov.ua/UJRN/Npchduped_2012_188_176_18].
} 
власний досвід, діяти в критичних ситуаціях, знаходити зв'язок між знаннями і конкретною практичною ситуацією ${ }^{21}$.

Щодо співвідношення понять «компетентність і «компетенція» в літературі існують різні підходи до визначення цих категорій: компетенція - складник компетентності; компетентність - це результат підготовки, а компетенція - коло повноважень; компетентність - поняття результативне, а компетенція - процесуальне; процес підготовки фахівців характеризується лише терміном «компетентність» або існує лише одне поняття для визначення рівня професійної підготовки, це - «компетенція»; існує загальна компетентність, яка складається з часткових компетентностей ${ }^{22}$.

Ми притримуємося думки тих науковців, які диференціюють поняття «компетентність» i «компетенція», але одночасно відмічаємо взаємозв'язок між цими дефініціями. Компетентність більш ширше поняття, виступає як інтегральна характеристика особистості, яка поєднує в собі знання, вміння, навички, а також професійні, світоглядні, громадянські і особистісні якості та морально-етичні цінності, що дозволяють виконувати певні професійні нестандартні завдання у соціально важливих сферах життєдіяльності людини і в постійно змінних умовах існування. Тоді як компетенція - вужче поняття, яке включає коло повноважень, які надані особі для виконання певних функцій; або компетенцією може бути коло питань, в яких людина добре обізнана і здатна діяти в стандартних ситуаціях.

Розглянемо детальніше соціальну i комунікативну компетентності. Так, соціальною компетентністю вважають здатність орієнтуватися в соціальних ситуаціях, взаємодіяти з оточуючими, знаходити підтримку інших людей, вміння визначати психоемоційний стан співрозмовника або колективу, обирати адекватні способи спілкування, а також досягати поставлених цілей у соціальній взаємодії. Зміст поняття соціальної компетентності включає знання про соціум, соціальну діяльність і соціальну дійсність в колективі, державі й у світі, а також вміння приймати

${ }^{21}$ Лейко С. В. Поняття «компетенція» та «компетентність»: теоретичний аналіз. Педагогічний процес: теорія і практика. 2013. Вип. 4. С. 128-135. URL: http://nbuv.gov.ua/UJRN/pptp_2013_4_15.

22 Дияк В. Теоретичні засади формування соціально-гуманітарної компетентності майбутніх фахівців. Збірник наукових праць Національної академії Державної прикордонної служби Украӥни. Сер. Педагогічні науки. 2016. № 5. C. 76-84. URL: http://nbuv.gov.ua/UJRN/znpnadpcpn_2016_5_9. 
рішення відповідно до соціальних потреб, передбачати наслідки для себе і колективу ${ }^{23}$.

Соціальну компетентність можна розглядати як чинник формування певного рівня і спрямування взаємин у соціумі, який може реалізуватися через такі форми вияву соціальних компетентностей, як координація (узгодженість i злагодженість поведінки), кооперація (продуктивна співпраця для досягнення спільної мети) і субординація (підпорядкування і підлеглість у разі нерівномірного доступу людей до знань, влади). Соціальна компетентність зумовлює характер вибірковості поведінки індивіда сприяє подоланню упередженості, розширенню потенціалу самореалізації і можливостей ${ }^{24}$.

Авторка С. Соболєва відмічає два підходи до визначення поняття «соціальна компетентність»: педагогічний підхід під соціальною компетентністю об'єднує особистісні властивості індивіда, потреби, цілі, здібності, знання, уміння і навички мислення, мовлення, спілкування, поведінки; соціальний підхід визначає соціальну компетентність як здатність орієнтуватися в мінливих життєвих ситуаціях, жити і співпрацювати в суспільстві ${ }^{25}$.

Узагальнюючи дані наукової літератури можна сформулювати власну думку щодо поняття «соціальної компетентності». Так, соціальна компетентність - це сукупність знань про суспільство, соціум, соціальну діяльність особистості в колективі, в закладі i в державі; сукупність умінь обирати способи спілкування, орієнтуватися в різних соціальних ситуаціях, приймати рішення відповідно до соціальних потреб з урахуванням інтересів оточуючих; сукупність правил, норм, цінностей і характеристик, які дозволяють налагоджувати соціальну взаємодію в мінливих життєвих умовах, інтегруватися в соціум і співпрацювати в суспільстві.

${ }^{23}$ Шпичко I.О. Зміст та структура соціальної компетентності майбутніх фахівців сфери обслуговування. Збірник наукових працьь Хмельницького ін-ту соціальних технологій Університету «Украӥна». 2013. № 2. C. 268-271. URL: http://nbuv.gov.ua/ UJRN/Znpkhist_2013_2_54.

${ }^{24}$ Глебова Н.І. Соціальна компетентність: соціологічні аспекти дослідження чинників успішної колективної професійної діяльності. Вісник НТУУ «КПІ». Політологія. Сочіологія. Право. 2017. Вип. 1/2 (33/34). С. 101-106.

${ }^{25}$ Соболєва С. Формування соціальної компетентності майбутніх фахівців з економіки у процесі викладання соціально-гуманітарних дисциплін. Педагогічні науки: теорія, історія, інноваційні технологї. 2018. № 2. С. 197-206. URL: http://nbuv.gov.ua/UJRN/pednauk_2018_2_21. 
Поняття «комунікативна компетентність» у науковій літературі розглядається 3 погляду кількох підходів. Інформаційний підхід передбачає вивчення психологічних особливостей прийому i передачі інформації, характеристик осіб, що спілкуються, засобів спілкування. Лінгвістичний підхід визначає мову як важливий інструмент спілкування, в центрі уваги знаходиться сфера мовної діяльності людини. Діяльнісний підхід розглядає комунікацію як вид діяльності, що зумовлює здатність людини вирішувати певні проблеми, здійснювати продуктивну співпрацю. Функція комунікації - це не лише передача або сприйняття інформації, а й взаєморозуміння, співпраця, вирішення колективних задач ${ }^{26}$.

Комунікативна компетентність має інтегративний характер, включає знання комунікацій, навички комунікування, мотивацію, відповідні особистісні якості, які дозволяють виконувати певні професійні завдання. Прослідковується зв'язок комунікацій особистості з ключовими компетенціями, виділеними Радою Європи. Так, наприклад, компетенції усного і письмового мовлення залежать від здатності особистості висловлювати свої думки, будувати діалог; інформаційні компетенції передбачають здатність комунікувати у соціальних інтернет-мережах, оцінювати достовірність інформації; політичні i соціальні компетенції потребують розвиненої здатності взаємодіяти і налагоджувати відносини з оточуючими 27 .

Поряд 3 комунікативною компетентністю часто розглядають поняття комунікативної толерантності, яку визначають як здатність взаємодіяти в рамках безконфліктної поведінки, приймати i визнавати цінності інших людей, поважне відношення до співрозмовника. Комунікативна толерантність передбачає терпимість по відношенню до партнера по спілкуванню, адаптацію до співрозмовника, прагнення досягти розуміння, узгодити різні погляди та установки без пригнічення один одного; наявність

${ }^{26}$ Добротвор О.В. Комунікативна компетентність як предмет наукового дослідження. Педагогічний прочес: теорія і практика. 2013. Вип. 3. С. 56-62. URL: http://nbuv.gov.ua/UJRN/pptp_2013_3_8.

7 Самборська Н.М. Комунікативна компетентність у структурі професійної компетентності майбутнього фахівця. Педагогічні науки. 2016. Вип. 1 (83). C. 126-130. 
емпатії, самоконтролю, витримки, інтелектуальної гнучкості та психологічної стійкості ${ }^{28}$.

Комунікативна толерантність передбачає терпимість по відношенню до партнера по спілкуванню, адаптацію до співрозмовника, прагнення досягти розуміння, узгодити різні погляди та установки без пригнічення один одного; наявність емпатії, самоконтролю, витримки, інтелектуальної гнучкості та психологічної стійкості. Толерантність лікаря відображає активну комунікативну позицію, психологічну готовність до спілкування з іншими людьми, які мають власні погляди, потреби, інтереси, переконання. Лікар має проявляти терпимість, емпатію, безконфліктну поведінку, дотримуватися правил і норм спілкування. Майбутній лікар повинен мати не лише професійні знання i вміння, а й володіти комунікативною толерантністю, а також мати мотивацію до професійної діяльності і спілкування, володіти певним стилем взаємовідносин і міжособистісної інтеракції.

Тобто комунікативна компетентність включає знання психологоемоційних характеристик людини, особливостей прийому i передачі інформації; володіння рідною та іноземною мовами i використовувати їх в різних ситуаціях, застосування в професійній діяльності інформаційних технологій; володіння культурою спілкування, вміння комунікувати і будувати діалог, що дозволяє виконувати певні професійні завдання.

Враховуючи описані вище характеристики комунікативної i соціальної компетентностей, можемо окреслити базове поняття «соціокомунікативна компетентність». Отже, соціокомунікативною компетентністю можна вважати сукупність знань, умінь і навичок, а також особистісних якостей, морально-етичних норм, людських цінностей, які забезпечують інтеграцію особистості в соціум, налагодженню ефективних комунікацій у професійній сфері, сприяють успішній самореалізації фахівця.

На нашу думку, поєднання двох компетентностей (соціальної і комунікативної) в одну є необхідним і доречним, оскільки соціальну компетентність як здатність до підтримання соціальних відносин неможливо розглядати окремо від комунікативної компетентності,

28 Логвинова О.К., Егорова У.Г., Бердиева А.Ш. Особенности коммуникативной толерантности студентов разной профессиональной направленности. МНКО. 2018. № 1 (68). C. 286-289. URL: https://cyberleninka.ru/article/n/ osobennosti-kommunikativnoy-tolerantnosti-studentov-raznoy-professionalnoynapravlennosti. 
яка визначає необхідні засоби та інструменти взаємодії, а також вказує механізм реалізації соціальної компетентності.

Враховуючи описані вище характеристики соціокомунікативної компетентності будь-якого фахівця, важливим $\epsilon$ виокремлення специфіки професійної діяльності лікаря.

Соціальний компонент професійної діяльності медика визначається такими особливостями: діяльність у галузі охорони здоров'я як соціальний процес, поетапне становлення професії лікаря в соціальних інституціях; постійна взаємодія із соціальними суб'єктами (пацієнти, лікарі, керівник, середній медперсонал, заклади охорони здоров'я), виконання певних соціальних ролей тощо.

Особливість комунікативного складника професії лікаря полягає у спілкуванні з пацієнтами, у яких може бути змінений психічний стан через хворобу; пошук індивідуальних засобів спілкування; можливість професійного вигорання; необхідність застосування новітніх засобів комунікації 3 метою здобуття нових знань i отримання певних умінь і навичок, необхідних для здійснення подальшої професійної діяльності.

3 огляду на це можемо визначити поняття «соціокомунікативна компетентність майбутнього лікаря» - це сукупність знань, умінь, навичок, досвіду, які забезпечують інтеграцію фахівця в медичний колектив як соціальну систему, здійснення ним професійної діяльності, а також самовдосконалення i самореалізація як особистості і професіонала.

Тому формування соціокомунікативної компетентності у майбутніх лікарів виступає одним із першочергових завдань вищої медичної освіти. Доречно буде дати визначення поняттю «формування». Так, академічний тлумачний словник української мови дає таке трактування терміну «формувати»- виробляти в комунебудь певні якості, риси характеру тощо, терміну «формуватися» ставати носієм певних якостей, визначатися, набувати рис завершеності, визначеності в результаті розвитку, змін.

Тож формування соціокомунікативної компетентності у майбутніх лікарів - це цілеспрямований процес розвитку у фахівців медичної сфери якісної характеристики, яка визначається сукупністю знань про соціальну діяльність, взаємодію із соціальними суб'єктами галузі охорони здоров'я, знань про психологічні особливості людини, а також умінь налагоджувати і здійснювати комунікації з оточуючими. 


\section{ВИСНОВКИ}

Таким чином, в процесі дослідження встановлено, що методологічною основою формування ключових компетентностей майбутніх лікарів $є$ компетентнісний підхід. Визначено, що 3 урахуванням специфіки професійної діяльності лікаря формування соціокомунікативної компетентності у майбутніх фахівців в галузі охорони здоров'я $\epsilon$ обов'язковим елементом їх професійної підготовки і запорукою подальшої успішної практичної діяльності. Соціокомунікативна компетентність повинна бути обов'язковим компонентом професіограми випускника вищого медичного навчального закладу, а також необхідною умовою професійної діяльності дорослих, яка дозволить особистості співвідносити свої цілі і бажання 3 інтересами і потребами оточуючих, створювати партнерські відносини 3 колегами, дотримуватися суспільної культури і правил поведінки.

На основі теоретичного аналізу наукової літератури 3'ясовано сутність понять «компетентність», «компетенція», «соціальна компетентність», «комунікативна компетентність»; окреслено базове поняття «соціокомунікативна компетентність» загалом, виокремлено специфіку соціального і комунікативного компонентів професійної діяльності лікаря, на основі чого уточнено визначення поняття «соціокомунікативна компетентність майбутнього лікаря» - це сукупність знань, умінь, навичок, досвіду, які забезпечують інтеграцію фахівця в медичний колектив як соціальну систему, здійснення ним професійної діяльності, а також самовдосконалення i самореалізація як особистості i професіонала. 3'ясовано, що «формування соціокомунікативної компетентності у майбутніх лікарів» - це цілеспрямований процес розвитку у фахівців медичної сфери якісної характеристики, яка визначається сукупністю знань про соціальну діяльність, взаємодію із соціальними суб'єктами галузі охорони здоров'я, знань про психологічні особливості людини, а також вмінь налагоджувати і здійснювати комунікації з оточуючими.

\section{АНОТАЦІЯ}

Стаття присвячена проблемі формування соціокомунікативної компетентності майбутніх лікарів у процесі вивчення природничих дисциплін. Підкреслено актуальність підготовки висококваліфікованих і компетентних фахівців медичної галузі 
із урахуванням вимог сучасного суспільства. Вказано на важливість впровадження компетентнісного підходу в систему професійної підготовки лікарів як методологічної основи формування соціокомунікативної компетентності спеціаліста. Встановлено, що наявність сформованої соціокомунікативної компетентності дозволить лікарю успішно інтегруватися в колектив i ефективно виконувати свої професійні обов'язки. Виокремлено основні особливості соціального i комунікативного складника професійної діяльності лікаря. Розкрито сутність основних понять: «компетентність», «компетенція», «соціальна компетентність», «комунікативна компетентність», «соціокомунікативна компетентність лікаря».

\section{ЛІТЕРАТУРА}

1. Антіпова Н.П. Сутність поняття «компетентнісний підхід» в науково-педагогічній літературі. Науковий вісник Національного університету біоресурсів і природокористування України. Серія : Педагогіка, психологія, філософія. 2014. Вип. 199(1). С. 28-32. URL: http://nbuv.gov.ua/UJRN/nvnau_ped_2014_199\%281\%29_5.

2. Великий тлумачний словник сучасної української мови : 250000 / укл. та гол. ред. В.Т. Бусел. Київ ; Ірпінь : Перун, 2005. VIII, $1728 \mathrm{c}$.

3. Воробьева А.В. Коммуникативная компетентность молодого специалиста медицинского профиля как одна из основных квалификационных составляющих его профессиональной деятельности. Вестник новых медицинских технологий, электронный журнал. 2017. № 2. С. 373-378. URL: https://cyberleninka.ru/article/ $\mathrm{n} /$ kommunikativnaya-kompetentnost-molodogo-spetsialistameditsinskogo-profilya-kak-odna-iz-osnovnyh-kvalifikatsionnyhsostavlyayuschih/viewer.

4. Глебова Н.І. Соціальна компетентність: соціологічні аспекти дослідження чинників успішної колективної професійної діяльності. Вісник НТУУ «КПІ». Політологія. Сочіологія. Право. 2017. Вип. 1/2 (33/34). С. 101-106.

5. Давискиба В.О. Проблема формування професійної компетентності фахівців у сучасних наукових дослідженнях. Духовність особистості: методологія, теорія і практика. 2017. Вип. 6. С. 75-81. URL: http://nbuv.gov.ua/UJRN/domtp_2017_6_11. 
6. Демянчук М.Р. Компетентнісний підхід до формування культури професійного спілкування майбутніх лікарів. Вісник Черкаського університету. 2016. Вип. 18. С. 45-51. URL: http://ped-ejournal.cdu.edu.ua/article/view/1153/1226.

7. Дияк В. Теоретичні засади формування соціальногуманітарної компетентності майбутніх фахівців. Збірник наукових праць Національної академії Державної прикордонної служби України. Сер. Педагогічні науки. 2016. № 5. С. 76-84. URL: http://nbuv.gov.ua/UJRN/znpnadpcpn_2016_5_9.

8. Добротвор О.В. Комунікативна компетентність як предмет наукового дослідження. Педагогічний прочес: теорія $і$ практика. 2013. Вип. 3. С. 56-62. URL: http://nbuv.gov.ua/UJRN/pptp_2013_3_8.

9. Закон України «Про вищу освіту» від 01.07.2014. № 1556-VII. URL: http://zakon4.rada.gov.ua/laws/show/1556-18.

10. Козлова Г.М. Методика викладання у вищій школі: навч. посібн. Одеса : НЕУ, ротапринт, 2014. 200 с.

11. Коммуникативный компонент содержания образования в аспекте корпоративной культуры медицинского вуза / Фомина М. В. и др. Вестник Оренбургского государственного университета. 2018. № 6 (218). C. 91-96. URL:https://cyberleninka.ru/article/n/ kommunikativnyy-komponent-soderzhaniya-obrazovaniya-v-aspektekorporativnoy-kultury-meditsinskogo-vuza/viewer.

12. Кустовська I.M. Компетентнісний підхід у професійній підготовці фахівця. Вісник Національної академї Державної прикордонної служби України. Сер. Педагогіка. 2015. Вип. 5. URL: http://nbuv.gov.ua/UJRN/Vnadped_2015_5_13.

13. Лейко С.В. Поняття «компетенція» та «компетентність»: теоретичний аналіз. Педагогічний процес: теорія і практика. 2013. Вип. 4. С. 128-135. URL: http://nbuv.gov.ua/UJRN/pptp_2013_4_15.

14. Леонтян М.А. Поняття «компетенція» і «компетентність» у теорії освіти. Наукові праці [Чорноморського держ. ун-ту ім. Петра Могили комплексу «Києво-Могилянська академія»]. Сер. Педагогіка. 2012. Т. 188, Вип. 176. С. 73-75. URL: http://nbuv.gov.ua/UJRN/Npchduped_2012_188_176_18.

15. Лимар Л.В. Зміст і складові професійної компетентності сімейного лікаря: психологічний аспект. Вісник післядипломної освіти. Серія «Соціальні та поведінкові науки». 2019. Вип. 8 (37). C. 67-83. DOI https://doi.org/10.32405/2522-9931-8(37)-67-83. 
16. Лимар Л.В. Основні компоненти соціальної компетентності сімейних лікарів в Україні. Медична освіта. 2019. № 2. С. 90-95. DOI 10.11603/me.2414-5998.2019.2.10101.

17. Логвинова О.К., Егорова У.Г., Бердиева А.Ш. Особенности коммуникативной толерантности студентов разной профессиональной направленности. МНКО. 2018. № 1 (68). С. 286-289. URL: https://cyberleninka.ru/article/n/osobennosti-kommunikativnoytolerantnosti-studentov-raznoy-professionalnoy-napravlennosti.

18. Лукаш Ю.М. Основні аспекти формування професійнокомунікативної компетентності студентів-медиків у процесі вивчення соціально-гуманітарних дисциплін. Вісник університету імені Альфреда Нобеля. Сер. Педагогіка і психологія. Педагогічні науки. 2018. № 1(15). С. 150-156.

19. Національна стратегія розвитку освіти в Україні на 20122021 роки. http://oneu.edu.ua/wp-content/uploads/2017/11/nsro_1221.pdf.

20. Овсієнко Л. Компетентнісний підхід до навчання: теоретичний аналіз. Педагогічний процес: теорія $і$ практика. 2017. Вип. 2. С. 82-87.

21. Павлюк Т.В., Толокова Т.І. Особливості емоційної сфери медичних працівників. Медична освіта. 2018. № 1. С. 103-107. URL: https://core.ac.uk/reader/276622410. DOI 10.11603/me.24145998.2018.1.8618.

22. Романовська О. Особливості організації процесу професійної підготовки студентів інженерно-педагогічних ВНЗ щодо проблеми формування їхньої конкурентноздатності. Молодь і ринок. 2015. № 5. C. 75-79. URL: http://nbuv.gov.ua/UJRN/Mir_2015_5_19.

23. Самборська Н.M. Комунікативна компетентність у структурі професійної компетентності майбутнього фахівця. Педагогічні науки. 2016. Вип. 1 (83). С. 126-130.

24. Соболєва С. Формування соціальної компетентності майбутніх фахівців з економіки у процесі викладання соціальногуманітарних дисциплін. Педагогічні науки: теорія, історія, інноваиійні технології. 2018. № 2. С. 197-206. URL: http://nbuv.gov.ua/ UJRN/pednauk_2018_2_21. DOI 10.24139/2312-5993/2018.02/197-206.

25. Сисоєва С.О., Соколова I.В. Теорія і практика вищої освіти: навчальний посібник. 2016. 338 с.

26. Сучасний тлумачний словник української мови : 50000 слів: оптимальна добірка слів з усіх галузей знань / за ред. В.В. Дубічинського. Київ : Школа, 2006. 832 с. 
27. Указ Президента України «Питання європейської та євроатлантичної інтеграції» від 20.04.2019 № 155/2019. URL:https://zakon.rada.gov.ua/go/155/2019.

28. Шпичко I.О. Зміст та структура соціальної компетентності майбутніх фахівців сфери обслуговування. Збірник наукових праць Хмельницького ін-ту сочіальних технологій Університету «Украӥна». 2013. № 2. С. 268-271. URL: http://nbuv.gov.ua/UJRN/ Znpkhist_2013_2_54.

\section{Information about the authors:}

Shevchuk T. I.,

Ph.D. in Medical Sciences, Associate Professor, Associate Professor at the Department of Medical Biology

National Pirogov Memorial Medical University 56, Pirohova str., Vinnytsia, 21000, Ukraine

Khliestova S. S., Ph.D. in Pedagogic Sciences, Associate Professor at the Department of Medical Biology National Pirogov Memorial Medical University 56, Pirohova str., Vinnytsia, 21000, Ukraine 